See Article page 1193.

\section{Commentary: The elusive perfect criterion for aortic intervention}

\author{
John A. Elefteriades, MD, PhD (hon), and \\ Bulat A. Ziganshin, MD, PhD
}

Girardi and colleagues ${ }^{1}$ do an excellent job reviewing history and key concepts regarding prediction of adverse ascending aortic events. Their point that operations for the ascending aorta and aortic root have become progressively safer, so that earlier intervention can fairly be considered, is very well taken. We will address some important points of controversy raised by the superb review by Girardi and colleagues. ${ }^{1}$

\section{DO WE NEED RANDOMIZED SIZE-BASED TRIALS?}

The authors rightly point out that studies regarding the ascending aorta fall short of those for the abdominal aorta, where randomized trials of observation of small aneurysms have indeed been performed. ${ }^{2,3}$ Abdominal aortic rupture, which has been studied in randomized fashion, is certainly a very bad event. But, ascending aortic dissection is even worse, with instantaneous death likely occurring in the majority of cases. The recent noninvasive autopsy studies from Japan have shown us that the patients who survive to be diagnosed and treated for type A aortic dissection likely represent just the fortunate tip of the iceberg of death due to ascending aortic dissection. ${ }^{4,5} \mathrm{~A}$ full $8.3 \%$ of all sudden deaths in the Japanese emergency departments were shown to be due to ruptured type A aortic dissection-an order of magnitude higher frequency than experts in the field had expected. So, should we perform a randomized trial of surgery versus no surgery for patients who reach currently accepted

From the Aortic Institute at Yale-New Haven Hospital, Yale University School of Medicine, New Haven, Conn.

Disclosures: Dr Elefteriades: Principal, CoolSpine; Consultant for CryoLife; Data/ Safety Monitoring Board for Terumo. Dr Ziganshin has reported no conflicts of interest.

The Journal policy requires editors and reviewers to disclose conflicts of interest and to decline handling or reviewing manuscripts for which they may have a conflict of interest. The editors and reviewers of this article have no conflicts of interest.

Received for publication July 22, 2020; revisions received July 22, 2020; accepted for publication July 22, 2020; available ahead of print July 25, 2020.

Address for reprints: John A. Elefteriades, MD, PhD (hon), Aortic Institute at Yale New Haven, 789 Howard Ave, Clinic Building CB317, New Haven, CT 06510 (E-mail: john.elefteriades@yale.edu).

J Thorac Cardiovasc Surg 2021;161:1198-201

$0022-5223 / \$ 36.00$

Copyright (c) 2020 by The American Association for Thoracic Surgery

https://doi.org/10.1016/j.jtcvs.2020.07.071
Check for updates

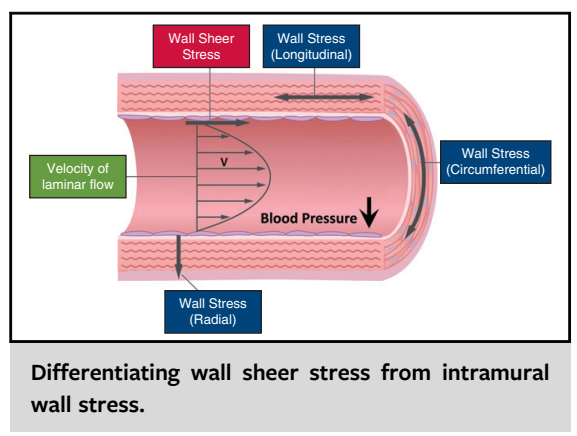

CENTRAL MESSAGE

Size-based predictions of

adverse events in thoracic aortic

disease remain the standard.

However, nongeometric param-

eters (eg, clinical and molecular

genetics) play an increasingly

important role.

size criteria for intervention? That is a serious and complex ethical question that deserves careful consideration. How about the patient with a smaller aorta and otherwise unexplained chest pain? How about the patient with a family history of aortic dissection? How about the patient with a demonstrated molecular genetic abnormality? Do we deny them surgical intervention in a randomized, size-based study? Can we ethically stand by while we believe the patient is in danger? Perhaps a randomized trial can be done, but these concerns need careful consideration.

In fact, there is an such an observational multicenter trial currently under way, the Canadian-led Treatment In Thoracic Aortic aNeurysm: Surgery versus Surveillance, which compares all-cause mortality in patients with aortic root and ascending aortic aneurysms in the narrow diameter between 5.0 and $5.4 \mathrm{~cm}$ undergoing early elective surgery or surveillance. Patients with known connective tissue disorders or familial aortopathy are excluded.*

\section{REAL-WORLD OBSERVATIONAL STUDY}

Although this was not a randomized clinical trial, we did recently carry out a "poor man's" observational study. ${ }^{6} \mathrm{We}$ examined outcomes after patients were triaged via a simple

\footnotetext{
* Appreciation is expressed to Dr Maral Ouzounian for this information. Trial leaders are Dr Jehangir Appoo (University of Calgary) and Dr Munir Boodhwani (University of Ottawa).
} 
algorithm based on aortic size and symptoms. Patients triaged to medical management did very well (only $3.3 \%$ total mortality). Patients triaged to surgery who refused or could not undergo operation (the "noncompliant" group) did very poorly ( $15.6 \%$ total mortality).

\section{IS AORTIC HEIGHT INDEX REALLY NOT CATCHING ON?}

The authors mention that aortic height index has never gained traction as a guideline for intervention. We are not certain that this is true or how this would be determined. We are very pleased with the aortic height index. This criterion eliminates the need to calculate body surface area by jettisoning weight entirely from the equation. After all, how does the aorta know or care that the patient has gained weight? The authors are correct that this criterion has not been incorporated into societal guidelines, but the latest US Guidelines ${ }^{7}$ are more than 10 years old—antedating the aortic size index.

\section{WILL 4-DIMENSIONAL MAGNETIC RESONANCE} IMAGING BE THE DECISION-MAKING SAVIOR?

Four-dimensional magnetic resonance imaging (which calculates anatomy in 3 dimensions and flow as the fourth dimension) does assess wall stress. However, it is important to recognize that this is not intramural wall stress (the stress that is tending to pull the aortic wall apart) but rather wall shear stress. Wall sheer stress represents the friction between the flowing blood and the endothelial lining of the aorta (Figure 1 shows various wall stress types acting on the aorta). This can be visualized as the impact of the flowing blood trying to pull the endothelial cells off their mooring. This is important regarding endothelial cell function and health, but not at all reflective of the actual mechanical force acting to disrupt the aortic wall. To calculate true wall stress, some measure of blood pressure, the stresscausing agent, needs to be incorporated. This is not an inherent part of 4-dimensional magnetic resonance imaging.

\section{CROSS-SECTIONAL AREA AS A CRITERION}

One important point needs to be made regarding use of aortic cross-sectional area as a criterion for intervention (aortic area/height ratio). We must remember the formula for cross-sectional area:

$$
\mathrm{A}=\Pi \mathrm{r}^{2}
$$

The only patient variable in this equation is $r$, the aortic radius. So, this formula really devolves to a diameterbased aortic height index. The rest is just arithmetic superimposed on one-half of the aortic diameter (or r).

\section{AORTIC VOLUME AS A CRITERION}

A similar observation can be made for volume-based indexes. The volume of a cylinder is just $\mathrm{V}=$ area $\times$ length. So, this devolves to diameter and length, which are accommodated in the studies that use diameter and length that are quoted by the authors. Again, no major new patient-related variables are incorporated by raising the calculation to volume, when one already has diameter and length. Nonuniformity of aortic wall contour may make computed

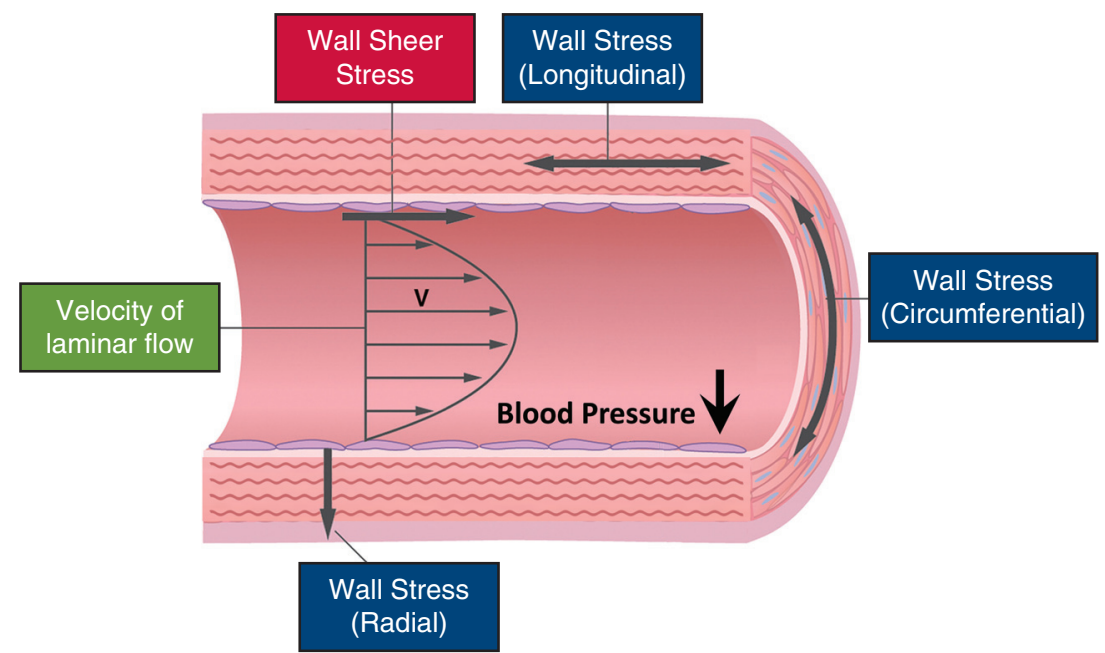

FIGURE 1. Schematic representation of different types of stress. The wall sheer stress that is calculated from 4-dimensional magnetic resonance imaging scans represents the friction between the flowing blood and the endothelial lining of the aorta, tending to pull the endothelial cells off their mooring. This is completely different from the traditional mechanical stress on the aortic wall, which is depicted in the longitudinal, circumferential, and radial directions. (Modified with permission from Whitlock MC, Hundley WG. Noninvasive imaging of flow and vascular function in disease of the aorta. JACC Cardiovasc Imaging. 2015;8:1094-106.) 
tomography scan-based volume measurements a bit more accurate that area $\times$ length, but the impact is small. Percent change in aneurysm volume over time has been shown to deviate only slightly $(2 \%)$ from percentage change in diameter. $^{8}$

\section{TIME FOR A "LEFT SHIFT"?}

Girardi and colleagues ${ }^{1}$ mention our suggestion that it may be time for a "left shift" to an earlier size criterion for intervention. Our team believes this is the case. ${ }^{9}$ We believe so for multiple reasons: (1) We are seeing earlier size hinge points for aortic events, now that growth of our database to approximately 4000 patients permits great granularity in our graphs. (2) It is now well established that the aorta grows approximately $8 \mathrm{~mm}$ at the moment of aortic dissection, ${ }^{10-12}$ meaning that the aorta was much smaller just before dissection than the pre-event measurements that have traditionally been used for intervention. ${ }^{3}$ The now ubiquitous, computerized centerline measurements underestimate aortic size compared with the traditional hand measurements on which our algorithms are based. (4) The availability of precise molecular genetic data in the present era often indicates earlier intervention for patients with known mutations. (5) Ascending aortic surgery is safer than ever before, with death and stroke rates for elective procedures below $2 \%$ at dedicated centers. ${ }^{13-15}$

\section{MACHINE LEARNING}

Ostberg and colleagues, ${ }^{16}$ from our team, have recently been applying machine learning and artificial intelligence to enhance decision-making in aortic disease. This holds considerable promise for the future.

\section{NONGEOMETRIC INDICATORS}

We must remember that geometric parameters (diameter, length, area, volume) are only one part of the picture. Multiple other criteria are emerging as important predictors of susceptibility to aortic events. Genetics play a major role, and different mutations (causing varying degrees of aortic wall weakness) require different intervention criteria ${ }^{17}$ (Figure 2). Family history plays an important role. ${ }^{18} \mathrm{We}$ have been investigating a promising biomarker, the "RNA signature" pattern of expression in peripheral blood. Our initial study ${ }^{19}$ was encouraging. Our follow-up study, still

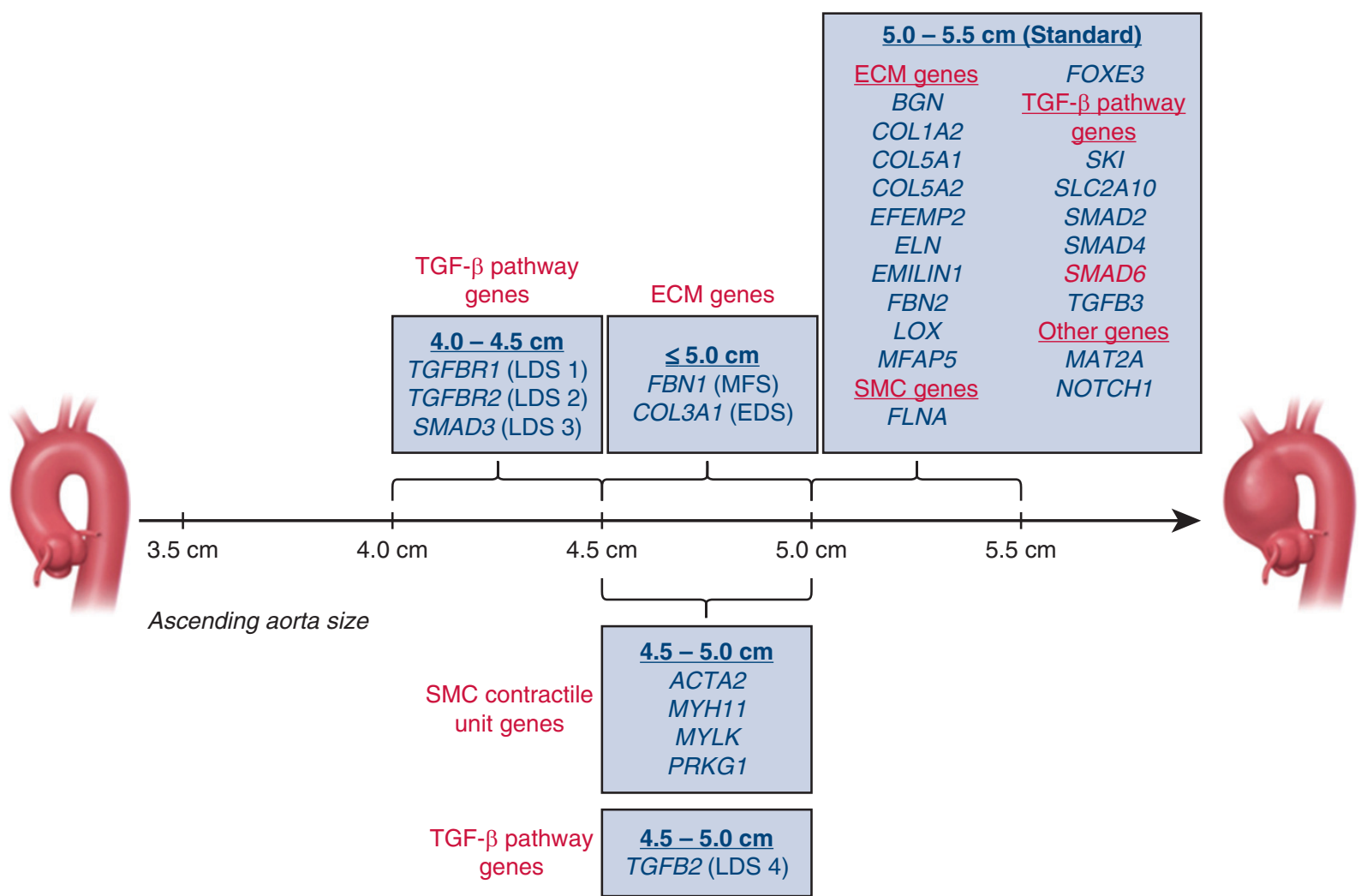

FIGURE 2. A dimensional "time line" of the recommended ascending aortic intervention size criteria for all currently known mutations that cause thoracic aortic aneurysm. $T G F-\beta$, Transforming growth factor beta; $E C M$, extracellular matrix; SMC, smooth muscle cell. (Reprinted with permission from Faggion Vinholo and colleagues. ${ }^{17}$ ) 
in progress, seems supportive on initial analysis. We must move beyond a strictly geometric orientation to decisionmaking.

The authors have done a great service to our specialty by reviewing clearly and insightfully the history and current status of dimensional criteria for prediction of aortic events and making valuable suggestions for future directions.

\section{References}

1. Girardi LN, Lau C, Gambardella I. Aortic dimensions as predictors of adverse events. J Thorac Cardiovasc Surg. 2021;161:1193-7.

2. Mortality results for randomised controlled trial of early elective surgery or ultrasonographic surveillance for small abdominal aortic aneurysms. The UK Small Aneurysm Trial Participants. Lancet. 1998;352:1649-55.

3. Lederle FA, Wilson SE, Johnson GR, Reidke DB, Littooy FN, Archer CW, et al. Immediate repair compared with surveillance of small abdominal aortic aneurysms. N Engl J Med. 2002;346:1437-44.

4. Tanaka Y, Sakata K, Sakurai Y, Yoshimuta T, Morishita Y, Nara S, et al. Prevalence of type A acute aortic dissection in patients with out-of-hospital cardiopulmonary arrest. Am J Cardiol. 2016;117:1826-30.

5. Moriwaki Y, Tahara Y, Kosuge T, Suzuki N. Etiology of out-of-hospital cardiac arrest diagnosed via detailed examinations including perimortem computed tomography. J Emerg Trauma Shock. 2013;6:87-94.

6. Saeyeldin A, Zafar MA, Li Y, Tanweer M, Gryasnov A, Brownstein AJ, et al. Decision-making algorithm for ascending aortic aneurysm: effectiveness in clinical application? J Thorac Cardiovasc Surg. 2019;157:1733-45.

7. Hiratzka LF, Bakris GL, Beckman JA, Bersin RM, Carr VF, Casey DE Jr, et al. 2010 ACCF/AHA/AATS/ACR/ASA/SCA/SCAI/SIR/STS/SVM guidelines for the diagnosis and management of patients with thoracic aortic disease. A Report of the American College of Cardiology Foundation/American Heart Association task force on practice guidelines, American Association for Thoracic Surgery, American College of Radiology, American Stroke Association, Society of Cardiovascular Anesthesiologists, Society for Cardiovascular Angiography and Interventions, Society of Interventional Radiology, Society of Thoracic Surgeons, and Society for Vascular Medicine. J Am Coll Cardiol. 2010;55:e27-129.

8. Trinh B, Dubin I, Rahman O, Botelho MPF, Naro N, Carr JC, et al. Aortic volumetry at contrast-enhanced magnetic resonance angiography: feasibility as a sensitive method for monitoring bicuspid aortic valve aortopathy. Invest Radiol. 2017;52:216-22.

9. Ziganshin BA, Zafar MA, Elefteriades JA. Descending threshold for ascending aortic aneurysmectomy: is it time for a "left-shift" in guidelines? J Thorac Cardiovasc Surg. 2019;157:37-42.

10. Mansour AM, Peterss S, Zafar MA, Rizzo JA, Fang H, Charilaou P, et al. Prevention of aortic dissection suggests a diameter shift to a lower aortic size threshold for intervention. Cardiology. 2018;139:139-46.

11. Rylski B, Blanke P, Beyersdorf F, Vallalbhajosyula P, Szeto WY, Milewski RK, et al. How does the ascending aorta geometry change when it dissects? J Am Coll Cardiol. 2014;63:1311-9.

12. Rylski B, Branchetti E, Bavaria JE, Vallalbhajosyula P, Szeto WJ, Milewski RK et al. Modeling of predissection aortic size in acute type A dissection: more than $90 \%$ fail to meet the guidelines for elective ascending replacement. $J$ Thorac Cardiovasc Surg. 2014;148:944-8 e941.

13. Ziganshin BA, Rajbanshi BG, Tranquilli M, Fang H, Rizzo JA, Elefteriades JA Straight deep hypothermic circulatory arrest for cerebral protection during aortic arch surgery: safe and effective. J Thorac Cardiovasc Surg. 2014;148:888-98; discussion 898-900.

14. Mok SC, Ma WG, Mansour A, Charilaou P, Chou AS, Peterss S, et al. Twentyfive year outcomes following composite graft aortic root replacement. J Card Surg. 2017;32:99-109.

15. Peterss S, Charilaou P, Dumfarth J, Li Y, Bhandari R, Tranquilli M, et al. Aortic valve disease with ascending aortic aneurysm: Impact of concomitant rootsparing (supracoronary) aortic replacement in nonsyndromic patients. J Thorac Cardiovasc Surg. 2016;152:791-8.e791.

16. Ostberg NP, Zafar MA, Ziganshin BA, Elefteraides JA. A Machine Learning Approach for Predicting Complications in Descending and Thoracoabdominal Aortic Aneurysms. In: American Association of Thoracic Surgery Aortic Symposium 2020, April 23-24, 2020, New York, NY.

17. Faggion Vinholo T, Brownstein AJ, Ziganshin BA, Zafar MA, Kuivaniemi H, Body SC, et al. Genes associated with thoracic aortic aneurysm and dissection: 2019 update and clinical implications. Aorta (Stamford). 2019;7: 99-107.

18. Ma WG, Chou AS, Mok SCM, Ziganshin BA, Charilaou P, Zafar MA, et al Positive family history of aortic dissection dramatically increases dissection risk in family members. Int J Cardiol. 2017;240:132-7.

19. Wang Y, Barbacioru CC, Shiffman D, Balasubramanian S, Iakoubova O Albornoz G, et al. Gene expression signature in peripheral blood detects thoracic aortic aneurysm. PLoS One. 2007;2:e1050. 